\title{
The Effects of Structural Lightweight Concrete on Energy Performance and Life Cycle Cost in Residential Buildings
}

\author{
Safa Nayır', Ümit Bahadır ${ }^{1}$ Şakir Erdoğdu', Vedat Toğan ${ }^{1 *}$ \\ ${ }^{1}$ Civil Engineering Department, Karadeniz Technical University, Trabzon, P.O.B. 61080, Turkey \\ * Corresponding author, e-mail: togan@ktu.edu.tr
}

Received: 03 September 2020, Accepted: 07 January 2021, Published online: 20 January 2021

\begin{abstract}
Energy efficiency in the construction industry is crucial to reducing increased energy consumption. A significant portion of the energy is consumed in residential buildings. Thermal properties of the materials used in the building envelope can reduce the energy consumed in the buildings and thus contribute to the building economy. For this purpose, in the study, structural lightweight concretes (SLWC) with a lower thermal conductivity than normal weight concrete (NWC) were produced and energy efficiency and life cycle costs were compared between these concretes on a $1+1$ reference flat. The compressive strength, unit weights and thermal conductivity coefficients of SLWCS and NWC were determined experimentally. Heating and cooling energy consumption and life cycle costs for the flat were calculated using the DesignBuilder simulation program according to the different concrete types produced. The results indicate that the thermal conductivity coefficients of all SLWCs produced were about $37-45 \%$ lower than those of NWC. All mixes of the SLWCS provided energy saving by about 18-25\% compared to the NWC and two SLWCs reduced the life cycle cost by $4 \%$. In addition, the results showed that the best SLWC about energy was not the best SLWC about life cycle cost.
\end{abstract}

Keywords

energy efficiency, life cycle cost, lightweight concrete, thermal conductivity, unit weight

\section{Introduction}

It has been increasingly revealing in a striking way that the developments occurring in particular some prominent areas, i.e., technology, industry etc., result in rapidly increasing energy demand. Moreover, environmental problems such as climate change, global warming, depletion of natural resources etc. caused by this inevitable increase show themselves more markedly. To minimize these kinds of problems a series of mandatory and encouraging policies have been implementing in many sectors especially in developed and developing countries [1]. Among these sectors, the construction sector consumes a significant amount of energy, such as $40 \%$ of the total energy consumption [2]. Therefore, increasing the energy efficiency in the construction sector has become an important issue.

The amount of energy consumed in buildings has a significant effect in reducing the energy in the construction industry [3]. Buildings need energy during their life cycle from its construction to demolition. Some studies have shown that the embodied and operating phases of energy occupy an important area in the energy demand of buildings.
Sustainable designs are required to reduce energy usage at these stages. For these designs, energy saving and the usage of materials in the construction sector are of great importance [4]. Several studies are reported in the literature for embodied energy and structural optimization [5]. Embodied energy is the energy used in the construction phase of buildings such as the production of materials, their transportation to the construction site, and the construction of buildings. Operating energy, on the other hand, is the energy required for HVAC (Heating, Ventilating and Air Conditioning), hot water usage, lighting and devices. It varies according to the comfort level, climate conditions and the operating program of the building.

Since non-renewable materials such as concrete are used extensively in buildings, optimization methods have been developed to reduce the use of concrete [6]. Yoon et al. [7] investigated the embodied energy and carbon dioxide $\left(\mathrm{CO}_{2}\right)$ emissions of a reinforced concrete column in order to create a sustainable design method. Thanks to the proposed design method, it has provided 
an effective optimization of both parameters. In a similar study, it is stated that reinforced concrete structures cause environmental pollution as well as consuming resources in the world and more environmental-friendly structures can be obtained with a sustainable design [8]. Alcalá et al. [9] offer an approach for embodied energy optimization of prestressed concrete slab bridge decks due to the high use of concrete in bridges as in buildings. In the study, it is also found that optimum energy designs are close to optimum cost designs, but the best cost solutions are not the best energy solutions. Quaglia et al. [10] demonstrates that energy and structural efficiency for heating and cooling should be examined together.

It is stated in the literature that the operating energy (80-90\%) has a large part compared to the embodied energy (10-20\%) throughout the life cycle of the buildings. Therefore, the reduction of operating energy is of great importance to construct a sustainable building. Passive and active measures such as increasing insulation on external walls and roofs, using windows with low thermal conductivity, solar photovoltaic panels can be used to reduce operating energy [5]. The energy required for heating and cooling of buildings is an important part of the operation energy consumed in buildings. During the design stages of the buildings, the heating and cooling loads can be reduced according to the climatic characteristics of the region and the design parameters of the building. The heating and cooling load are caused by the heat transmission arising from the elements forming the building envelope and the air infiltration at the joints of these elements [11]. Generally, the building envelope consists of walls, floors, roofs, windows and doors [12]. In a survey of existing buildings in Turkey, heat losses occurring through the building envelope are $25 \%$ in the roof, $25 \%$ in opening, $15 \%$ in walls and $20 \%$ in building structural system. In addition, heat gains in the building envelope are $25-35 \%$ in the roof, $25-35 \%$ in the windows, $15-25 \%$ in the walls, $10-20 \%$ in the ground floors and 5-25\% in air infiltration [13]. When these data are taken into consideration, the thermal properties of the materials used in the buildings have great importance for designing energy and cost-effective buildings.

In the literature, there are many studies investigating the effects of building envelope on energy performance of buildings. Some of these studies have examined the effect of different roof types on the energy performance of buildings. Generally, studies have shown that green and photovoltaic roofs offer many benefits such as reducing rainwater flow, improving air quality, reducing energy costs for heating and cooling, and shading and absorbing sunlight [14]. Thermal insulation thicknesses were also analyzed [15]. It is concluded from this study that an average of $9 \%$ efficiency can be achieved in building heating and cooling loads with optimum thermal insulation thickness values obtained according to climate regions instead of standard thermal insulation thicknesses. Some researchers examined different building elements together such as roof, window, window/wall ratio, and shading devices and investigated their effects in terms of energy efficiency [16, 17]. Raji et al. [16] presented optimizing one parameter at each step and achieved energy saving $42 \%$ for total energy use, $64 \%$ for heating and $34 \%$ for electric lighting. Later on, a study conducted in the hot and humid climate zone shows that building components have a strong interaction with each other and that energy consumption in buildings is reduced with this relationship [17]. In addition to these studies, there are studies examining energy performance and life cycle cost together [18]. It is stated that with the simulation and life cycle cost models developed with passive and active energy methods, a $13.5 \%$ saving has been achieved [19].

Using materials with lower thermal conductivity can reduce energy consumption. One of the most used materials in buildings is concrete. Therefore, it is important to use concretes with lower thermal conductivity. In order to achieve this, structural lightweight concretes (SLWC) can be preferred. Although there are many studies regarding mechanical and durability properties of SLWC, there are few numbers of studies on the evaluation of the energy performance and life cycle cost of the SLWC. In one of these studies, Real et al. [20] state that when using SLWC instead of normal weight concrete (NWC) in buildings in European countries, $15 \%$ savings in heating energy can be achieved.

This paper aims to investigate the effect of SLWC with low thermal conductivity on the energy consumption and life cycle cost for a building and the results obtained were compared with NWC. For this purpose, 8 different SLWCs were produced and tested for determining the unit volume weight, compressive strength and thermal conductivity. Energy performance analysis and life cycle cost of produced concrete mixes were compared using the data obtained. Dynamic building energy simulation software, known as DesignBuilder, was employed for energy performance analysis. 


\section{Structural lightweight concrete}

Lightweight concretes produced by creating voids in different ways in concrete or using lower unit weight aggregates compared to normal aggregates have a history of more than two thousand years [21]. In lightweight concrete production, lightweight aggregates with high pore amounts are used compared to normal aggregates. Aggregates used in production can be obtained from natural or industrial waste materials. Pumice, expanded perlite, diatomite, expanded clay, volcanic slag, tuff, slate, expanded slate, lightweight fly ash aggregate and thermal power plant ashes are used in the lightweight concrete production. The fine lightweight aggregate used for structural concrete should meet upper limits for loose bulk density $1120 \mathrm{~kg} / \mathrm{m}^{3}$, for lightweight coarse aggregate $880 \mathrm{~kg} / \mathrm{m}^{3}$ and $1040 \mathrm{~kg} / \mathrm{m}^{3}$ for combined fine and coarse aggregate according to ASTM C330 [22].

Lightweight concretes are classified according to their compressive strength and unit weights, and one of the lightweight concrete classes is SLWC. Compared to other lightweight concretes, SLWCs are used as structural elements in buildings (column, roof elements, slabs and roofs). SLWC has several advantages over NWC. By using SLWC, the dead load of the structure decreases, thus contributing to the reduction of the cross-sectional areas of columns, beams and other bearing elements. With the use of SLWC in buildings, more efficiency is provided compared to NWC in terms of strength/weight [23].

Thanks to the porous structure of lightweight concrete and the air gaps in it, it has a low thermal conductivity coefficient compared to normal concrete. With these features, the use of SLWC in buildings is of great importance in terms of insulation and energy performance [24]. In the studies, it is emphasized that buildings have an important share in energy consumption. In this context, compared to normal weight concrete, SLWC with lower thermal conductivity coefficient can be used at the energy consumption reduction point in buildings [25]. In a study conducted on the thermal conductivity coefficient of SLWC, it is stated that the thermal conductivity coefficient of SLWC in the same dosage is $40-53 \%$ lower than NWC, depending on the lightweight aggregate type [26].

According to the ACI 213R-14 standard, a minimum compressive strength of $21 \mathrm{MPa}$ is recommended for SLWC [27]. According to the TS 2511 standard, SLWC are defined as concretes with a unit volume weight of $1400-2000 \mathrm{~kg} / \mathrm{m}^{3}$, with a compressive strength of at least 17.2 MPa and suitable for use as a structural element in structures [28]. According to TS EN 206 standard, concretes with an oven dry unit volume weight of $800-2000 \mathrm{~kg} / \mathrm{m}^{3}$ are defined as SLWC [29].

\section{Methods}

In the study, 8 different combinations of SLWCs were produced with one NWC as a reference. Thermal conductivity coefficients, unit weights and compressive strengths of SLWCs and reference concrete are determined according to the relevant standards. The thermal conductivity coefficient and unit weights that affect the thermal properties of the concrete were taken into consideration, it is calculated approximately how much the total energy consumption in a flat can change depending on the type of mixtures a flat. For this purpose, a flat with $1+1$ typical floor plan for a family of two is used in cold climate in Turkey. This building is located in Ankara, in Climate Region III, a cold climate. It is aimed to the effects of different concrete types (SLWCs with different binary and ternary blends) on the zone heating and cooling loads of buildings were investigated. In this context, a flat in which all parameters (such as air conditioning, lighting system and occupants etc.) were kept constant except the unit weight and thermal conductivity of concrete were used for energy performance analysis. Through DesignBuilder energy simulation software, heating and cooling loads for the concrete types mentioned in the next section were calculated monthly and annually. Then, for each concrete with different unit weight and thermal conductivity, the life cycle costs were calculated by summing the initial capital investment and the annual energy operational cost. Finally, the energy and cost efficiency of the produced concrete types were compared with NWC. The flowchart used in this study is presented in Fig. 1.

\subsection{Materials and mixture compositions}

Within the scope of the experimental study, 8 different SLWCs and NWC were produced. Pumice aggregate used as coarse lightweight aggregate and raw perlite, limestone aggregate were used as normal aggregates. The mixing proportions of pumice, raw perlite and normal fine aggregates were determined as $20 \%, 30 \%$ and $50 \%$, respectively for SLWCs. The maximum size of aggregate was $16 \mathrm{~mm}$. Granulometry of the mixture aggregate provided the appropriate boundary conditions as specified in TS 2511 [28] and in accordance with TS 802 [30] standards. Coarse and fine aggregates were used for NWC and mix proportions determined as $40 \%$ and $60 \%$, 


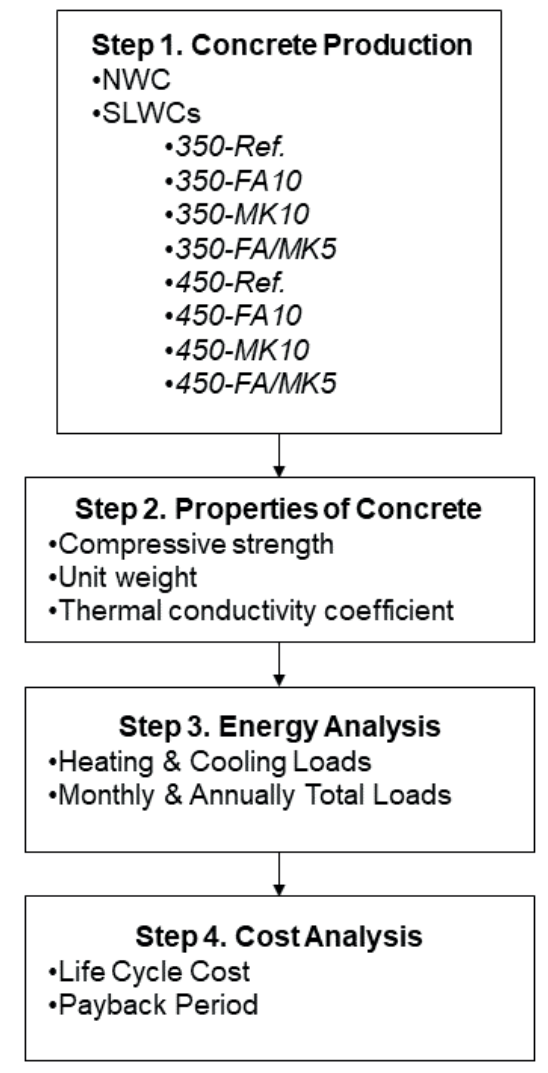

Fig. 1 Flowchart of the methodology

respectively. CEM I 42.5 $\mathrm{R}$ type cement was used and the physical, chemical and mechanical properties of cement are given in Table 1. Two types of mineral additives, fly ash and metakaolin, were used in the experimental study. Chemical composition of mineral additives and aggregates are given Table 2. The superplasticizer was used in the mixes to ensure same consistency class in the mixes.

Table 3 shows concrete mixtures proportion. In the experimental study, water/cement ratio is determined as 0.40 for all SLWCs. In the experimental study, F type fly ash and metakalolin are used binary and ternary blends.
Table 1 Chemical composition, physical and mechanical properties of cement

\begin{tabular}{|c|c|c|c|c|}
\hline \multicolumn{2}{|c|}{ Chemical composition } & \multicolumn{3}{|c|}{ Physical and Mechanical Properties } \\
\hline Components & $(\%)$ & Retained on sieve $45 \mu \mathrm{m}$ & $\%)$ & 9.8 \\
\hline $\mathrm{SiO}_{2}$ & 19.46 & Retained on sieve $90 \mu \mathrm{m}$ & $\%)$ & 1.0 \\
\hline $\mathrm{Al}_{2} \mathrm{O}_{3}$ & 5.11 & Specific surface (Blaine) & $\left.\mathrm{m}^{2} / \mathrm{kg}\right)$ & 412.6 \\
\hline $\mathrm{Fe}_{2} \mathrm{O}_{3}$ & 3.31 & Specific gravity $\left(\mathrm{g} / \mathrm{cm}^{3}\right)$ & & 3.12 \\
\hline $\mathrm{CaO}$ & 60.23 & \multirow{2}{*}{$\begin{array}{l}\text { Setting Times (Vicat) } \\
(\mathrm{min})\end{array}$} & Initial & 140 \\
\hline $\mathrm{MgO}$ & 2.08 & & Final & 200 \\
\hline $\mathrm{SO}_{3}$ & 3.05 & Water Demand (\%) & & 29.2 \\
\hline $\mathrm{Na}_{2} \mathrm{O}$ & 0.27 & Soundness (mm) & & 1.0 \\
\hline $\mathrm{K}_{2} \mathrm{O}$ & 0.69 & \multirow{3}{*}{$\begin{array}{l}\text { Compressive strength } \\
(\mathrm{MPa})\end{array}$} & 2-day & 28.0 \\
\hline $\mathrm{Cl}-$ & 0.02 & & 7-day & 40.4 \\
\hline $\begin{array}{l}\text { Loss on } \\
\text { Ignition (LOI) }\end{array}$ & 3.00 & & 28-day & 51.5 \\
\hline
\end{tabular}

Table 2 Chemical composition of the materials

\begin{tabular}{|c|c|c|c|c|}
\hline $\begin{array}{l}\text { Chemical } \\
\text { composition (\%) }\end{array}$ & Perlite & Pumice & Fly Ash & Metakaolin \\
\hline $\mathrm{SiO}_{2}$ & 72.05 & 71.21 & 49.4 & 51.4 \\
\hline $\mathrm{Al}_{2} \mathrm{O}_{3}$ & 13.09 & 12.37 & 19.9 & 45.2 \\
\hline $\mathrm{Fe}_{2} \mathrm{O}_{3}$ & 1.53 & 1.44 & 11.3 & 0.702 \\
\hline $\mathrm{MgO}$ & 0.39 & 0.11 & - & - \\
\hline $\mathrm{CaO}$ & 1.34 & 0.77 & 4.35 & 0.301 \\
\hline $\mathrm{Na}_{2} \mathrm{O}_{3}$ & 3.91 & 3.62 & - & - \\
\hline $\mathrm{K}_{2} \mathrm{O}$ & 4.18 & 4.86 & 2.50 & 0.122 \\
\hline $\mathrm{Ba}$ & 0.02 & 0.01 & - & - \\
\hline $\mathrm{Cr}_{2} \mathrm{O}_{3}$ & 0.01 & 0.01 & - & - \\
\hline $\mathrm{MnO}$ & 0.07 & 0.07 & - & - \\
\hline $\mathrm{SO}_{3}$ & 0.015 & 0.067 & 1.75 & - \\
\hline $\mathrm{P}_{2} \mathrm{O}_{5}$ & 0.01 & $<0.01$ & 0.120 & 0.0824 \\
\hline $\mathrm{Sr}$ & 0.003 & $<0.002$ & - & - \\
\hline $\mathrm{TiO}_{2}$ & 0.05 & 0.09 & 0.811 & 1.88 \\
\hline LOI & 3.0 & 4.4 & - & - \\
\hline
\end{tabular}

Table 3 Concrete mixtures proportion $\left(\mathrm{kg} / \mathrm{m}^{3}\right)$

\begin{tabular}{|c|c|c|c|c|c|c|}
\hline Mixes & Cement & Water & Water/Cement & Fly Ash & Metakaolin & Total Aggregate \\
\hline NWC & 350 & 210 & 0.60 & - & - & 1719 \\
\hline 350-Ref. & 350 & 140 & 0.40 & - & - & 1400 \\
\hline $350-F A 10$ & 315 & 140 & 0.40 & 35 & - & 1395 \\
\hline 350-MK10 & 315 & 140 & 0.40 & - & 35 & 1401 \\
\hline 350-FA/MK5 & 315 & 140 & 0.40 & 17.5 & 17.5 & 1397 \\
\hline 450-Ref. & 450 & 180 & 0.40 & - & - & 1260 \\
\hline $450-\mathrm{FA} 10$ & 405 & 180 & 0.40 & 45 & - & 1237 \\
\hline 450-MK10 & 405 & 180 & 0.40 & - & 45 & 1245 \\
\hline 450-FA/MK5 & 405 & 180 & 0.40 & 22.5 & 22.5 & 1243 \\
\hline
\end{tabular}




\subsection{Test methods and measurements}

For each mixture, four $15 \mathrm{~cm}$ cubic specimens were produced. Compressive strength of concretes at 28 days were determined according to EN 12390-3 standard [31]. All of the lightweight concretes produced have met the limit conditions for the SLWC. The thermal conductivity test was performed according to ASTM C 518 (heat flow meter principle) [32]. $30 \times 30 \times 5 \mathrm{~cm}$ sized specimens were produced to determine thermal conductivity coefficient. Before thermal conductivity test performed, specimens were kept at $100-105^{\circ} \mathrm{C}$ in oven until specimens reached a constant weight. Thermal conductivity coefficients and unit weights of concrete produced are given Table 4.

Unit weights of SLWCs were between $1880-1893 \mathrm{~kg} / \mathrm{m}^{3}$. The unit weight of NWC is $2250 \mathrm{~kg} / \mathrm{m}^{3}$. Unit weights of SLWCs were $15-16 \%$ lower than NWC. The thermal conductivity coefficient of SLWCs ranges from 0.548 $0.63 \mathrm{~W} / \mathrm{mK}$. The thermal conductivity of SLWCs were $37-45 \%$ lower than NWC. In a study on thermal conductivity and unit volume weight of concrete, it is stated that pumice aggregate reduces the unit volume weight and thermal conductivity of concrete by approximately $40 \%$ and $46 \%$, respectively [33].

Compressive strengths of mixes at 28 days are given Table 5. The compressive strengths of SLWCs are between 20-26 MPa. All lightweight concretes produced within the scope of the experimental study met the limit conditions specified for SLWC in the relevant standards.

\subsection{Building information}

For energy performance and cost efficiency analysis, a $1+1$ flat for a family of 2 was used in the reference residential building project with different concrete types. The flat is located in Ankara, in Climate Region III, which is accepted a cold climate of Turkey. The floor plan of the flat and the zones for this plan are shown in Fig. 2. The building, with a total floor area of $45.88 \mathrm{~m}^{2}$, has a living room + kitchen, a bedroom and a bathroom. The height of the reference flat is $3 \mathrm{~m}$. This building, which has three thermal zones, faces southwest.

The flat has both exterior and partition walls. The composition of the exterior and partition walls is the same. The thickness of the exterior walls is $20 \mathrm{~cm}$ thick concrete produced from each concrete mix and the partition walls are $10 \mathrm{~cm}$. Floors and the roof consist of the same composition as used for walls. The roof of the investigated flat is not a pitched roof since the flat is an intermediate

\begin{tabular}{lccc} 
Table 4 Thermal conductivity coefficients and unit weight of concretes \\
\hline Mixes & $\begin{array}{c}\text { Thermal conduc- } \\
\text { tivity coefficient } \\
(\mathrm{W} / \mathrm{mK})\end{array}$ & $\begin{array}{c}\text { Reduction in thermal } \\
\text { conductivity according } \\
\text { to NWC }(\cong \%)\end{array}$ & $\begin{array}{c}\text { Unit } \\
\text { weight } \\
\left(\mathrm{kg} / \mathrm{m}^{3}\right)\end{array}$ \\
\hline NWC & 1.00 & - & 2250 \\
350-Ref. & 0.63 & 37 & 1893 \\
350-FA10 & 0.57 & 43 & 1885 \\
350-MK10 & 0.615 & 38 & 1891 \\
350-FA/MK5 & 0.59 & 41 & 1888 \\
450-Ref. & 0.588 & 41 & 1890 \\
450-FA10 & 0.548 & 45 & 1880 \\
450-MK10 & 0.573 & 42 & 1886 \\
450-FA/MK5 & 0.55 & 45 & 1884 \\
\hline
\end{tabular}

Table 5 Compressive strength of mixes at 28 days

\begin{tabular}{lc}
\hline Mixes & Compressive strength (MPa) \\
\hline NWC & 28.00 \\
350-Ref. & 21.69 \\
$350-F A 10$ & 21.04 \\
350-MK10 & 25.80 \\
350-FA/MK5 & 24.35 \\
$450-$ Ref. & 23.02 \\
$450-F A 10$ & 21.88 \\
$450-M K 10$ & 25.90 \\
$450-F A / M K 5$ & 25.27 \\
\hline
\end{tabular}

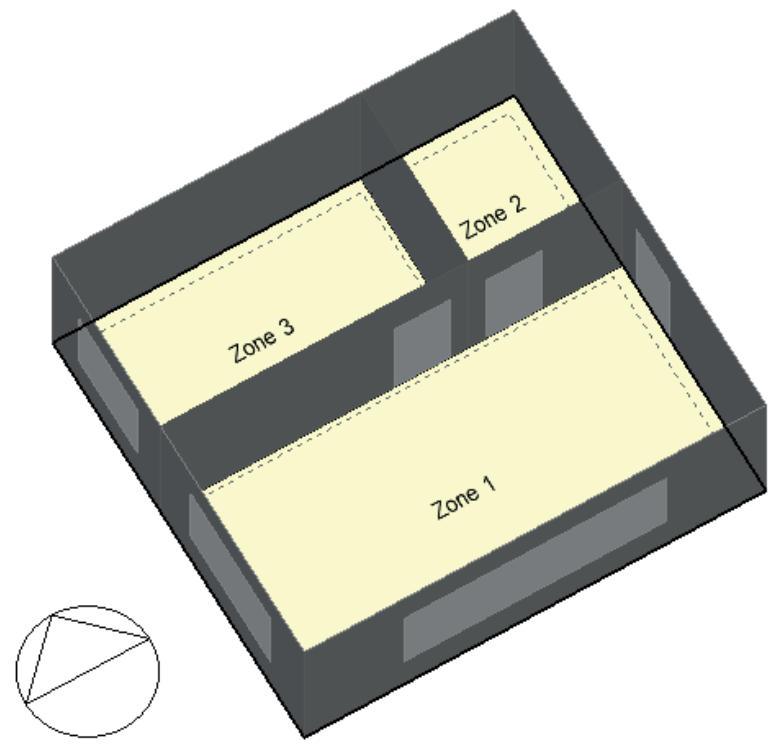

Fig. 2 Floor plans and zones of flat

floor. Table 6 shows the heat transmittance coefficients (U-value) of the exterior walls, partition walls, floors and roofs. As the $U$ values of the building elements decrease, their heat protection performances increase. 
The windows $(3+13+3 \mathrm{~mm})$ for each apartment created using different concrete mixtures are the same on all facades and the window/wall ratio is $30 \%$.

\subsection{Meteorological data}

The building model were located in Ankara $\left(40.12^{\circ} \mathrm{N}\right.$, $33.00^{\circ} \mathrm{E}$, altitude $949 \mathrm{~m}$ ), in Climate Region III, representing the cold climate of Turkey. Meteorological data for Turkey's Climate Region III is given in Table 7 [34].

\subsection{DesignBuilder energy simulation software}

Dynamic building energy simulation software DesignBuilder v.6.1.3 is used to calculate monthly and annual heating and cooling loads in the flats. This software uses EnergyPlus dynamic thermal simulation software widely accepted within the literature for calculating thermal performance of a building with multiple zones located in different climates and occupancy schedules conditions. With this software, users decide on parameters such as occupancy schedules, heating and cooling operating periods, air conditioning system and lighting that affect the thermal performance of the building [35].

Table 6 The $U$ values $\left(\mathrm{W} / \mathrm{m}^{2} \mathrm{~K}\right)$ of the building elements

\begin{tabular}{lcccc}
\hline Mixes & Exterior walls & Partition walls & Floors & Roofs \\
\hline NWC & 2.703 & 2.778 & 2.439 & 2.941 \\
350-Ref. & 2.051 & 2.388 & 1.896 & 2.186 \\
350-FA10 & 1.920 & 2.297 & 1.783 & 2.037 \\
350-MK10 & 2.019 & 2.366 & 1.868 & 2.150 \\
350-FA/MK5 & 1.965 & 2.328 & 1.822 & 2.088 \\
450-Ref. & 1.960 & 2.325 & 1.818 & 2.083 \\
450-FA10 & 1.869 & 2.260 & 1.739 & 1.980 \\
450-MK10 & 1.927 & 2.301 & 1.789 & 2.045 \\
450-FA/MK5 & 1.851 & 2.246 & 1.723 & 1.959 \\
\hline
\end{tabular}

\subsection{Life cycle cost analysis}

Life cycle cost is total cost of ownership of machinery, equipment, or building elements including the initial investment, maintenance/repair/operation, replacement, and destruction cost. In order to evaluate a unit in terms of life cycle cost, all future costs over the life of the unit have been discounted to the present value of the project, excluding the initial capital investment. The following formula (Eq. (1)) is used to calculate the life cycle cost (LCC) [36]:

$$
L C C=I+M-R-O+R-R V
$$

Within the scope of the study, as the maintenance/ repair and replacement costs are not available from the Turkish concrete companies, these costs were ignored and the initial investment and operation costs were taken into account in the life cycle cost analysis (LCCA). Table 8 gives the parameters used in LCCA.

Cubic meters unit prices of 9 different concrete used in the study were obtained the concrete companies in Turkey. Based on the total volume of concrete in the flat, a total of nine initial capital investments are calculated for each flat. The cubic meter cost of concrete units and the initial investment cost of concrete types used in the flats are given in Table 9.

Since precise data on maintenance and repair costs cannot be obtained from concrete companies, energy expenditures are used in the operation cost calculation in the study. The unit price of natural gas and electricity used in the calculation of energy expenditures is taken from the official website of the distributor companies in Ankara [37, 38]. Energy expenditures have been updated using present worth analysis.

In this study, the discount rate for projects in Turkey by the International Finance Association has been proposed as $15 \%$. The study period was determined as 30 years. The dis-

Table 7 Meteorological data for Ankara

\begin{tabular}{|c|c|c|c|c|c|c|c|c|c|c|c|c|}
\hline & JAN & FEB & MAR & APR & MAY & JUN & JUL & AUG & SEP & OCT & $\mathrm{NOV}$ & DEC \\
\hline Outside temperature $\left({ }^{\circ} \mathrm{C}\right)$ & -1.1 & 0.9 & 5.8 & 10.5 & 15.5 & 19.9 & 23.6 & 23.6 & 18.0 & 12.5 & 5.8 & 0.8 \\
\hline Dewpoint temperature $\left({ }^{\circ} \mathrm{C}\right)$ & -4.4 & -3.9 & -1.3 & 2.2 & 5.7 & 8.6 & 9.0 & 9.0 & 6.7 & 4.1 & 1.0 & -2.4 \\
\hline Wind speed $\left(\mathrm{m}^{2} / \mathrm{s}\right)$ & 1.9 & 2.3 & 2.7 & 2.6 & 2.4 & 2.8 & 3.1 & 3.0 & 2.3 & 2.1 & 1.7 & 1.8 \\
\hline Atmospheric pressure $(\mathrm{hPa})$ & 909 & 909 & 911 & 913 & 914 & 916 & 917 & 917 & 915 & 913 & 911 & 909 \\
\hline Relative humidity (\%) & 78 & 70 & 60 & 56 & 52 & 48 & 39 & 39 & 48 & 56 & 71 & 79 \\
\hline Global radiation horizontal $\left(\mathrm{W} / \mathrm{m}^{2}\right)$ & 69 & 98 & 131 & 194 & 220 & 267 & 271 & 237 & 176 & 120 & 91 & 74 \\
\hline Direct radiation horizontal $\left(\mathrm{W} / \mathrm{m}^{2}\right)$ & 32 & 47 & 50 & 105 & 105 & 156 & 162 & 145 & 90 & 55 & 48 & 43 \\
\hline Diffuse radiation horizontal $\left(\mathrm{W} / \mathrm{m}^{2}\right)$ & 38 & 51 & 81 & 89 & 115 & 111 & 108 & 92 & 86 & 64 & 43 & 31 \\
\hline
\end{tabular}


Table 8 Parameters used in the LCCA

\begin{tabular}{lc}
\hline Analysis type & $\begin{array}{c}\text { General LCCA, non-federal, } \\
\text { no taxes }\end{array}$ \\
\hline Beginning date for LCC & 2018 \\
Study period & 30 years \\
Planning/Construction period & 2 years \\
Discount rate & $15 \%$ \\
Life of concrete & $30-40$ years \\
Fuel type & Natural gas and electricity \\
The unit cost of natural gas (for 2020) & $0.0268 \$ / \mathrm{kWh}$ \\
The unit cost of electricity (for 2020) & $0.079 \$ / \mathrm{kWh}$ \\
\hline
\end{tabular}

Table 9 Cost of concrete units and total initial investment cost

\begin{tabular}{lcc}
\hline Concrete types & Supply price $/ \mathrm{m}^{3}(\$)$ & Initial capital investment (\$) \\
\hline NWC & 35.2941 & 1279.9765 \\
350-Ref. & 45.2941 & 1642.6365 \\
350-FA10 & 42.3529 & 1535.9718 \\
350-MK10 & 48.2353 & 1749.3012 \\
350-FA/MK5 & 46.1765 & 1674.6359 \\
$450-$ Ref. & 48.5294 & 1759.9676 \\
$450-F A 10$ & 46.3235 & 1679.9691 \\
$450-M K 10$ & 49.9266 & 1810.6373 \\
$450-F A / M K 5$ & 48.2353 & 1749.3012 \\
\hline
\end{tabular}

count factor was obtained from the table depending on the discount rate and study period. Table 10 shows the yearly energy costs of the concrete types used in the flats.
Table 10 Yearly energy expenditures $(\$)$

\begin{tabular}{lc}
\hline Concrete types & Yearly energy cost $(\$)$ \\
\hline NWC & 423.513028 \\
350-Ref. & 372.405996 \\
350-FA10 & 364.398628 \\
$350-$ MK10 & 371.864806 \\
$350-F A / M K 5$ & 367.707052 \\
$450-$ Ref. & 367.336352 \\
$450-F A 10$ & 360.780786 \\
$450-M K 10$ & 364.349024 \\
$450-F A / M K 5$ & 358.848874 \\
\hline
\end{tabular}

\section{Results and discussions}

After the simulation, the monthly heating and cooling loads for produced concrete mixes according to Ankara were obtained, as shown in Fig. 3.

According to the results obtained, it is observed that SLWCs consume less total annual energy than NWC. The SLWCs have lower total annual loads compare to NWC ranging from $18 \%$ to $25 \%$, on average. Especially, 450-FA/MK5 concrete provide the most energy saving compared to other concretes types. In a similar study conducted in European countries, it was stated that approximately $15 \%$ of heating energy was saved due to the use of SLWC instead of NWC in apartments. In addition to these results, considering the total energy consumed during the heating period (from the beginning of October

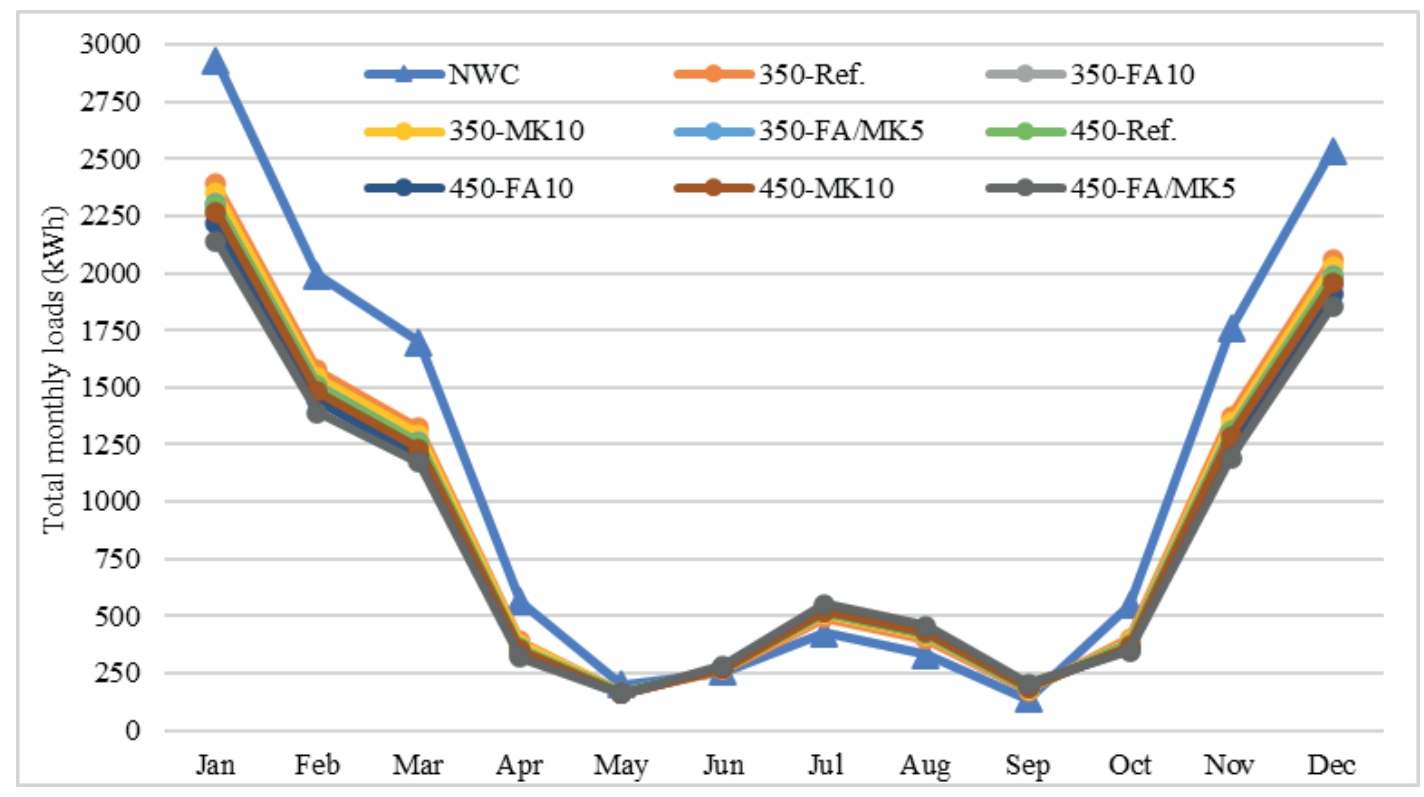

Fig. 3 Total monthly loads in Ankara 


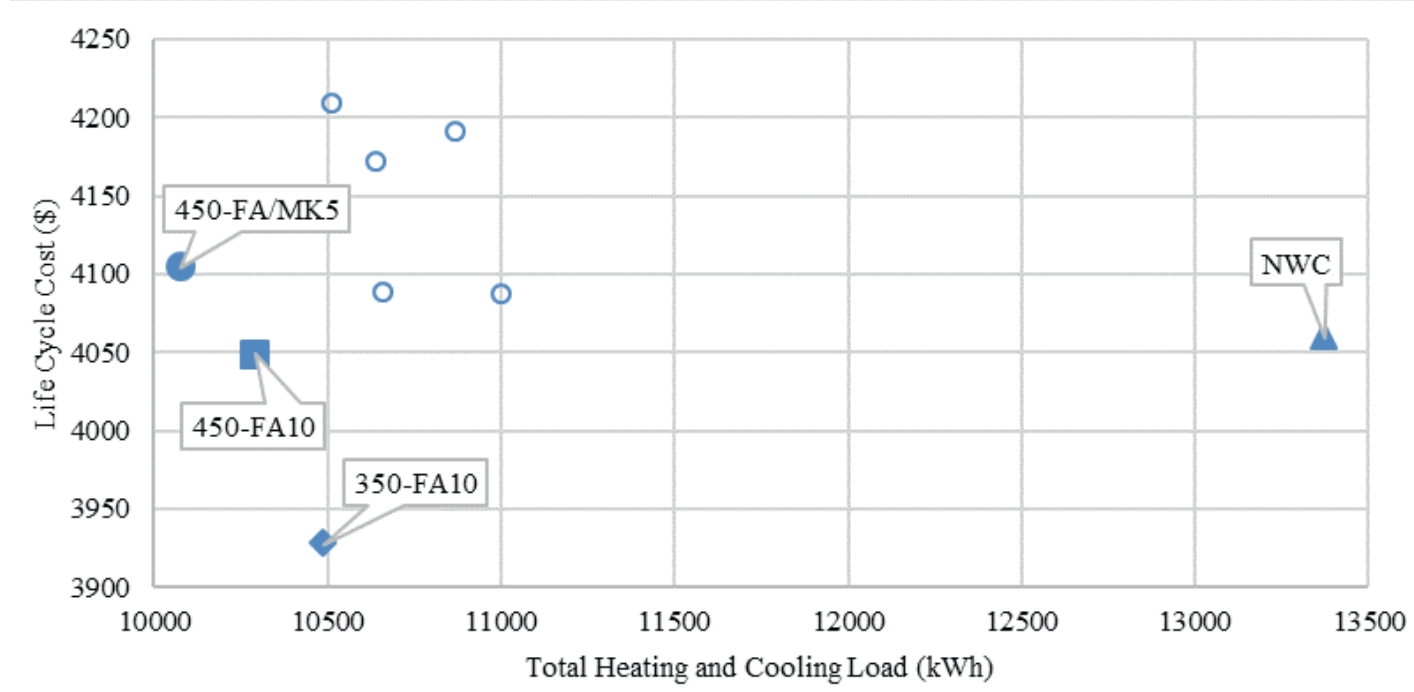

Fig. 4 The total annual loads and life cycle costs of all concrete mixes

to the end of March), energy efficiency of SLWCs is clearly observed. However, no significant difference was found between the total energy consumption of SLWCs and NWC during the cooling period (from the beginning of April to the end of September).

As shown in Fig. 4, the most energy and cost efficient combinations are 450-FA/MK5 and 350-FA10. Although life cycle costs of all lightweight concrete types (except 350-FA10 and 450-FA10) are higher than those of NWC, total annual energy savings of these concretes are higher than NWC. According to LCCA, using 350-FA10 cause $4 \%$ more cost saving compared to NWC. And also, when using 350-FA10 in the reference building, $22 \%$ less energy is consumed than NWC. Although 450-FA/MK5 is the most effective in terms of energy efficiency, the life cycle cost is higher than NWC.

The initial investment payback periods of 350-FA10 and 450-FA10 with life cycle cost lower than NWC are 4.33 and 6.37 years, respectively. The initial investment payback period of $450-\mathrm{FA} / \mathrm{MK} 5$, which has the lowest total energy consumption, is 7.26 years.

\section{Conclusions}

Within the scope of the study, the energy and economic efficiency of the produced 8 SLWCs and the NWC were investigated according to simulation results for cold climate region. For simulation, a typical flat with a $1+1$ floor plan was used. The thermal conductivity and unit weight of the concretes produced in the study were measured experimentally and the annual heating and cooling loads of the buildings of each concrete type were calculated using these data with DesignBuilder energy simulation software. The results of the study can be summarized as follows:

- All the lightweight concretes produced have met the criteria provided for SLWC by the relevant standards. The thermal conductivity coefficients of concretes increased with the increase in unit weight of concretes. The thermal conductivity coefficients of SLWCs were about $37-45 \%$ lower than the conductivity coefficient of NWC.

- The unit weights of SLWCs and NWC are ranging between 1880 and $2250 \mathrm{~kg} / \mathrm{m}^{3}$. The compressive strength of concretes was improved with increasing in the density of concretes.

- The 450-FA/MK5 has the highest energy efficiency performance in terms of total annual energy consumption. 450-FA/MK5 provided $25 \%$ more energy-saving than NWC.

- When the heating energy during the heating period is analyzed, 450-FA/MK5 is the most efficient concrete type and contributed to $3393.36 \mathrm{kWh}$ less energy consumption than NWC.

- In terms of life cycle cost, 350-FA10 and 450-FA10 are the most economically efficient concrete types.

- In terms of payback period, 350-FA10 is the best alternative, due to its lower initial capital investment compared to other SLWCs.

Consequently, in terms of energy and economic efficiency, 350-FA10 and 450-FA10 should be preferred in Ankara, with a cold climate, for long term investment, 
as opposed to NWC. In terms of energy efficiency, all concrete types perform better than NWC thanks to their lower thermal conductivity. The study covers the cold climate regions in Turkey. The effectiveness of these concrete types can be investigated in other climatic regions. In addition, structural and energy optimization can provide more information about energy efficiency in future works.

\section{References}

[1] Bahadır, Ü., Thomollari, X., Toğan, V. "Evaluation of energy-cost efficient design alternatives for residential buildings", Journal of Construction Engineering, Management \& Innovation, 1(1), pp. 43-54, 2018.

https://doi.org/10.31462/jcemi.2018.01043054

[2] Martí, J. V., García-Segura, T., Yepes, V. "Structural design of precast-prestressed concrete U-beam road bridges based on embodied energy", Journal of Cleaner Production, 120, pp. 231-240, 2016.

https://doi.org/10.1016/j.jclepro.2016.02.024

[3] Ustaoglu, A., Kurtoglu, K., Gencel, O., Kocyigit, F. "Impact of a low thermal conductive lightweight concrete in building: Energy and fuel performance evaluation for different climate region", Journal of Environmental Management, 268, Article No. 110732, 2020. https://doi.org/10.1016/j.jenvman.2020.110732

[4] Yüksek, İ. "The Evaluation of Building Materials in Terms of Energy Efficiency", Periodica Polytechnica Civil Engineering, 59(1), pp. 45-58, 2015.

https://doi.org/10.3311/PPci.7050

[5] Ramesh, T., Prakash, R., Shukla, K. K. "Life cycle energy analysis of buildings: An overview", Energy and Buildings, 42, pp. 1592$1600,2010$.

https://doi.org/10.1016/j.enbuild.2010.05.007

[6] Penadés-Plà, V., García-Segura, T., Yepes, V. "Accelerated optimization method for low-embodied energy concrete box-girder bridge design", Engineering Structures, 179, pp. 556-565, 2019.

https://doi.org/10.1016/j.engstruct.2018.11.015

[7] Yoon, Y.-C., Kim, K.-H., Lee, S.-H., Yeo, D. "Sustainable design for reinforced concrete columns through embodied energy and $\mathrm{CO}_{2}$ emission optimization", Energy and Buildings, 174, pp. 44-53, 2018.

https://doi.org/10.1016/j.enbuild.2018.06.013

[8] Yu, R., Zhang, D., Yan, H. "Embodied Energy and Cost Optimization of RC Beam under Blast Load", Mathematical Problems in Engineering, 2017, Article ID 1907972, 2017. https://doi.org/10.1155/2017/1907972

[9] Alcalá, J., González-Vidosa, F., Yepes, V., Martí, J. V. "Embodied Energy Optimization of Prestressed Concrete Slab Bridge Decks", Technologies, 6(2), Article No. 43, 2018. https://doi.org/10.3390/technologies6020043

[10] Quaglia, C. P., Yu, N., Thrall, A. P., Paolucci, S. "Balancing energy efficiency and structural performance through multi-objective shape optimization: Case study of a rapidly deployable origami-inspired shelter", Energy and Buildings, 82, pp. 733-745, 2014.

https://doi.org/10.1016/j.enbuild.2014.07.063

\section{Nomenclature}

I Initial capital investment

LCCA Life cycle cost analysis

M-R-O Maintain-Repair-Operation cost

NWC Normal weight concrete

R Replacement cost

RV Residual value

SLWC Structural lightweight concrete

[11] Yaşar, Y., Maçka Kalfa, S. "The effects of window alternatives on energy efficiency and building economy in high-rise residential buildings in moderate to humid climates", Energy Conversion and Management, 64, pp. 170-181, 2012.

https://doi.org/10.1016/j.enconman.2012.05.023

[12] Sozer, H. "Improving energy efficiency through the design of the building envelope", Building and Environment, 45, pp. 2581-2593, 2010 .

https://doi.org/10.1016/j.buildenv.2010.05.004

[13] NIRAS International Consulting "Binalarda Enerji Sistemleri ve Ölçüm Yöntemleri" (Energy Systems and Measurement Methods in Buildings), Ministry of Environment and Urbanisation of Turkish Republic, Ankara, Turkey, 2016. [in Turkish]

[14] Omar, A. I., Virgone, J., Vergnault, E., David, D., Idriss, A. I. "Energy Saving Potential with a Double-Skin Roof Ventilated by Natural Convection in Djibouti", Energy Procedia, 140, pp. 361373, 2017.

https://doi.org/10.1016/j.egypro.2017.11.149

[15] Saylam Canım, D., Aydın, Ö. "Energy performance evaluation of energy performance calculation method in buildings (Bep-Tr1)", Journal of Construction Engineering, Management \& Innovation, 2(1), pp. 18-29, 2019. https://doi.org/10.31462/jcemi.2019.01018029

[16] Raji, B., Tenpierik, M. J., van den Dobbelsteen, A. "An assessment of energy-saving solutions for the envelope design of high-rise buildings in temperate climates: A case study in the Netherlands", Energy and Buildings, 124, pp. 210-221, 2016.

https://doi.org/10.1016/j.enbuild.2015.10.049

[17] Mirrahimi, S., Mohamed, M. F., Haw, L. C., Ibrahim, N. L. N., Yusoff, W. F. M., Aflaki, A. "The effect of building envelope on the thermal comfort and energy saving for high-rise buildings in a hot-humid climate", Renewable and Sustainable Energy Reviews, 53, pp. 1508-1519, 2016.

https://doi.org/10.1016/j.rser.2015.09.055

[18] Kumar, G. K., Babu, T. P. A. "Study of Various Glass Materials to Provide Adequate Day Lighting in Office Buildings of Warm and Humid Climatic Zone in India", Energy Procedia, 109, pp. 181-189, 2017.

https://doi.org/10.1016/j.egypro.2017.03.090

[19] Hajare, A., Elwakil, E. "Integration of life cycle cost analysis and energy simulation for building energy-efficient strategies assessment", Sustainable Cities and Society, 61, Article No. 102293, 2020. https://doi.org/10.1016/j.scs.2020.102293 
[20] Real, S., Gomes, M. G., Rodrigues, A. M., Bogas, J. A. "Contribution of structural lightweight aggregate concrete to the reduction of thermal bridging effect in buildings", Construction of Building Materials, 121, pp. 460-470, 2016.

https://doi.org/10.1016/j.conbuildmat.2016.06.018

[21] Thienel, K.-C., Haller, T., Beuntner, N. "Lightweight Concrete-From Basics to Innovations", Materials, 13(5), Article No. 1120, 2020. https://doi.org/10.3390/ma13051120

[22] ASTM "ASTM C330/330M-17a Standard Specification for Lightweight Aggregates for Structural Concrete", ASTM International, West Conshohocken, PA, USA, 2017. https://doi.org/10.1520/C0330_C0330M-17A

[23] Iqbal, S., Ali, A., Holschemacher, K., Ribakov, Y., Bier, T. A. "Effect of Fly Ash on Properties of Self-Compacting High Strength Lightweight Concrete", Periodica Polytechnica Civil Engineering, 61(1), pp. 81-87, 2017. https://doi.org/10.3311/PPci.8171

[24] Bogas, J. A. "Characterization of structural lightweight expanded clay aggregate concrete", $\mathrm{PhD}$ Thesis, Technical University of Lisbon, 2011.

[25] Pérez-Lombard, L., Ortiz, J., Pout, C. "A review on buildings energy consumption information", Energy and Buildings, 40, pp. 394-398, 2008.

https://doi.org/10.1016/j.enbuild.2007.03.007

[26] Real, S., Bogas, J. A., da Glória Gomes, M., Ferrer, B. "Thermal conductivity of structural lightweight aggregate concrete", Magazine of Concrete Research, 68(15), pp. 798-808, 2016. https://doi.org/10.1680/jmacr.15.00424

[27] ACI "ACI 213R-14 Guide for Structural Lightweight Aggregate Concrete", American Concrete Institute, Farmington Hills, MI, USA, 2014.

[28] TSE "TS 2511 Mix Design for Structural Lightweight Aggregate Concrete", Turkish Standards Institution, Ankara, Turkey, 2017.

[29] TSE "TS EN 206 Concrete - Specification, Performance, Production and Conformity", Turkish Standards Institution, Ankara, Turkey, 2017.
[30] TSE "TS 802 Design of Concrete Mixes", Turkish Standards Institution, Ankara, Turkey, 2016.

[31] TSE "TS EN 12390-3 Testing Hardened Concrete-Part 3: Compressive Strength of Test Specimens", Turkish Standards Institution, Ankara, Turkey, 2019.

[32] ASTM "ASTM C518-17 Standard Test Method for Steady-State Thermal Transmission Properties by Means of the Heat Flow Meter Apparatus", ASTM International, West Conshohocken, PA, USA, 2017. https://doi.org/10.1520/C0518-17

[33] Uysal, H., Demirboğa, R., Şahin, R., Gül, R. "The effects of different cement dosages, slumps, and pumice aggregate ratios on the thermal conductivity and density of concrete", Cement and Concrete Research, 34(5), pp. 845-848, 2004. https://doi.org/10.1016/j.cemconres.2003.09.018

[34] Turkish State Meteorological Service "Weather forecast - Ankara" [online] Available at: https://mgm.gov.tr/eng/forecast-cities.aspx [Accessed: 15 March 2018]

[35] DesignBuilder Software Ltd. "User's manual for DesignBuilder v6" [online] Available at: https://designbuilder.co.uk/download/documents [Accessed: 02 March 2019]

[36] Fuller, S. National Institute of Standards and Technology "LifeCycle Cost Analysis (LCCA)", [online] Available at: https://www. wbdg.org/resources/life-cycle-cost-analysis-lcca

[37] GazElektrik "Enerjisa Ankara - Başkent Elektrik Birim Fiyat ve Tarifeleri" (Enerjisa Ankara - Başkent Electricity Unit Prices and Tariffs), [online] Available at: https:/gazelektrik.com/tedarikciler/ enerjisa-ankara/birim-fiyat [Accessed: 23 May 2020] [in Turkish]

[38] Başkent Doğalgaz Dağıtım Gayrimenkul Yatırım Ortaklığı A. Ş. "Doğal Gaz Perakende Satış Tarifeleri ve Fiyatları" (Natural Gas Retail Tariffs and Prices), [online] Available at: https://www. baskentdogalgaz.com.tr/Images/upload/dokumanlar/2020_ yili_MAYIS_ayi_perakende_satis_tarifeleri_ve_fiyatlari.pdf [Accessed:23 May 2020] [in Turkish] 